OMEGA, Vol. 33(1) 21-42, 1996

\title{
A CRITICAL REVIEW OF THE CONCEPT OF PATHOLOGICAL GRIEF FOLLOWING PREGNANCY LOSS
}

\author{
HETTIE J. E. M. JANSSEN, PH.D. \\ MARIAN C. J. CUISINIER, PH.D. \\ KEES A. L. HOOGDUIN, M.D., PH.D. \\ University of Nijmegen, The Netherlands
}

\begin{abstract}
It has often been suggested in the literature on pregnancy loss, that parents run a high risk of complicated or pathological grief as a result of the specific characteristics of such loss. What confuses the issue is that pathological grief has been defined in various ways. In the interest of improving professional care, it is important to ascertain how pathological grief manifests itself and which parents are most likely to have problems coping with pregnancy loss and therefore develop pathological grief reactions. Given the lack of clarity regarding the concept of pathological grief following pregnancy loss, this article reviews empirical studies on pathological grief following pregnancy loss according to four subtypes derived from general bereavement literature: chronic grief, delayed grief, masked grief, and exaggerated grief. It can be concluded that in the first six months following pregnancy loss, psychological complaints, behavioral changes, and somatic complaints are fairly common responses. Approximately 10-to-15 percent of the women develop a psychiatric disorder during the first two years following such loss, and less than 10 percent seek specific psychiatric care. Parents often mourn the loss of their baby for more than a year; one in five women is unable to accept pregnancy loss after approximately two years. A delayed grief reaction occurs in about 4 percent of parents and seems to occur most often in men. It is suggested that developing pathological grief following pregnancy loss may be more uncommon than had previously been thought, and the long-held idea that parents run a higher risk of pathological grief following pregnancy loss seems partly to result from flaws in the empirical studies in this field. A large majority of women seem to be able to recover from pregnancy loss in due time, drawing on their own strength.
\end{abstract}

(C) 1996, Baywood Publishing Co.,Inc doi: 10.2190/YLL0-MW 4-WG http://baywood.com 
The psychological impact of pregnancy loss on parents has long been a neglected subject of study. Research in this area began only two decades ago [1-4]. Contrary to earlier beliefs, it is now common knowledge that parents mourn their lost baby and that bereavement reactions resemble those observed in individuals who have lost a significant other. Following pregnancy loss, parents experience feelings of shock and disbelief [5, 6], of anger, guilt, and intense distress [7-9]. Such reactions as depressed mood, feelings of anxiety and irritability, sleeping and eating disturbances, lessened activity or apathy, and decreased self-respect are also often reported $[6,7,9-12]$. All of these are considered to be quite normal grief reactions. However, many authors suggest that in a pregnancy loss there is a relatively high risk of complicated, disturbed or "pathological" mourning, due to the specific characteristics of this kind of traumatic event. Doka indicated that pregnancy loss was a socially unrecognized loss, and that therefore the loss could become "disenfranchised" and the grief complicated [13]. Social support may be minimal or totally lacking since members of the social network often did not see the child, and particularly in the case of early miscarriage, may not even have known about the pregnancy [8, 14-21]. For the parents themselves, pregnancy loss lacks reality, since sometimes they did not even see the baby, and, particularly often in early pregnancy loss, no funeral or any other kind of memorial service is held [14-16, $18,21-24]$. When parents lose their child, they also lose their fantasies about the baby and the future. Therefore, they have to deal with a "double" loss $[14,20$, 25-27]. The mother in particular may experience a loss of self-esteem, because she might feel that she has failed as both a woman and a wife $[11,20]$. The loss represents a second crisis, following upon the crisis of pregnancy itself where a happy ending had been expected $[14,19,28,29]$. In most cases the loss is sudden and unexpected and therefore relatively difficult to deal with [25, 26]. Dealing with pregnancy loss can be further complicated by the fact that fathers and mothers grieve differently following pregnancy loss [20, 23, 30-32]. As the cause of the loss remains unknown in many cases, the mother may blame herself for the death of the baby and may experience strong feelings of guilt because she was the one who was carrying the child $[11,20,24,33]$.

Given the assumed relationship between a pregnancy loss and problematic mourning, several researchers have sought to determine which parents may be particularly at risk of developing more complicated grief reactions. Some important predisposing factors have been found. These are increased pregnancy length, mental health symptomatology prior to the loss, poor physical health prior to the loss, poor social support prior to the loss, and low marital quality prior to the loss [11, 34-37]. Knowing these factors is important for professional care. Furthermore, it helps to identify at an early stage whether particular parents are at risk, and they could be offered extra support to prevent the development of disturbed reactions. There is, however, a major problem in that there seems to be no consensus as to what constitutes "normal" and what constitutes "pathological" mourning [38]. As a consequence, researchers use a wide range of definitions and 
it remains questionable how often pathological mourning following a pregnancy loss really occurs and which parents are indeed at risk of complicated reactions. Given this situation, it would seem worthwhile to review the literature in order to gain a more accurate insight into which reactions following pregnancy loss can be expected to be normal in the course of grief and which responses seem to indicate problems dealing with such a loss.

In this article, the following questions will be addressed: 1) How is pathological grief following pregnancy loss defined? and 2) How often do parents develop pathological grief according to empirical studies on early pregnancy loss (miscarriage) and late pregnancy loss (stillbirth, perinatal loss, neonatal death)? In the discussion section of this chapter a more concordant definition of pathological grief following pregnancy loss will be suggested. Because the loss of a baby has much in common with the loss of a beloved older person, we will first discuss the relevant insights concerning normal and pathological grief from the general bereavement literature, before reviewing the pregnancy loss literature.

\section{GENERAL BEREAVEMENT STUDIES}

Studies into general bereavement have provided substantial knowledge on the process of mourning. As early as the 1940s, Lindemann wrote on the characteristic grief reactions of bereaved individuals [39]. Bowlby [40], Parkes [41] and KüblerRoss [42], described common grief responses in terms of phases, or stages of grief. As the bereaved individual had to detach emotionally from the deceased, it was supposed that he or she had to work through all of the phases of grief before mourning was finally resolved $[40,43]$. Although this attachment theory and the model of grief derived from it is still found to be the most useful concept within bereavement research [38], the stage model is nowadays more used as a tool for understanding the reactions the bereaved may experience. As Schuchter and Zisook summarize:

Grief is not a linear process with concrete boundaries but, rather a composite of overlapping, fluid phases that vary from person to person. Therefore stages are meant to be general guidelines only and do not prescribe where an individual "ought" to be grieving in the grieving process $[44$, p. 23].

Wortman and Silver even oppose the notion of "having to live through the emotions following a loss" as, in their opinion, not all individuals grieve for a loss [45].

With regard to the time needed for grieving, it used to be that the bereaved person was expected to recover from the loss "in a relatively short time." Peretz stated that normal grief could last up to six months or a year [46]. Parkes also mentioned six months as the usual grief period [47]. Nowadays, more authors 
agree that the time needed to grieve differs from individual to individual, and therefore a standard duration is hard to define [43]. It is thought that some individuals may continue to grieve endlessly over a loss [44, 45].

As it is more and more accepted that each individual can grieve over a loss in his own manner and at his own pace, the boundaries for those responses that are considered "normal" have become more flexible. It is therefore not surprising that there are no clear definitions of "normal" and "pathological" grief. According to Horowitz and his colleagues the inability to adapt after a loss experience is termed pathological grief [48]. Bowlby suggests that pathological grief distinguishes itself from healthy forms of grieving by the length of time during which grief persists and the extent to which mental functioning is influenced [40]. The length of time which he considers to be normal is, however, not defined. Middleton and colleagues see an intensification or inhibition of the phenomena of normal bereavement, or a delay or prolongation of the processes of normal grieving, as indicative of pathological grief [38]. It seems, then, that pathological grief reactions can be differentiated from normal responses to a loss by means of two axes; a "time axis" and an "intensity axis."

Several subtypes of pathological grief have been suggested in general bereavement research. Four of these are: delayed grief, chronic grief, masked grief, and exaggerated grief. Experts working in the field of bereavement believe the most readily in the existence of delayed grief and chronic grief [38]. In delayed grief, grief may be (almost) absent immediately following the loss and, as a consequence (re)appear to an excessive extent at a subsequent loss or at reminders of the former loss $[14,20,38,39,43,46,49,50]$. The time-span prior to the appearance of grief reactions may range from several days [50] to several months [46] or years [39]. In chronic grief, reactions are of excessive duration and the grieving process is not worked through satisfactorily $[14,20,38,40,43,46,49,50]$. Absent grief was the next subtype of pathological grief most often believed to exist by bereavement experts [38]. This is defined as a denial of feelings about the loss; the individual presents no external signs of grieving, and continues to act as though nothing has happened. Worden who refers to this type of pathological grief as "masked grief," believes that, since the grief is repressed, it generally manifests itself in one to two ways: it is masked either as a physical symptom or through some type of maladaptive behavior [43]. In both cases the bereaved does not connect these symptoms with the loss experience [43]. The term "masked grief" is used in this article to draw a clearer distinction from delayed grief. Opinions are divided on the existence of other subtypes of pathological grief [38]. There are those who label as "pathological grief" psychiatric disorders such as a clinical depression when they follow a loss $[43,51]$. Worden, who refers to the development of a psychiatric disorder following a loss as exaggerated grief, also includes anxiety disorders, post-traumatic stress disorder (PTSD), and substance-abuse disorder [43]. 


\section{PREGNANCY LOSS RESEARCH}

Researchers in the field of pregnancy loss have determined their own criteria for differentiating "pathological" grief from "normal" grief. Table 1 provides an overview of empirical studies on pregnancy loss, and the definitions used for pathological grief.

The empirical studies in the field of pregnancy loss will be discussed in relation to the four subtypes of pathological grief mentioned previously: delayed, chronic, masked, and exaggerated grief.

\section{Defining and Assessing Pathological Grief Following Pregnancy Loss}

Since delayed grief can only be assessed after a relatively long time, it has received relatively little attention. The majority of studies present no clear criteria with regard to the "time-axis" of the course of grief $[5,52,53]$. A problem concerning this kind of grief is that an absence of responses shortly following a loss may indicate feelings of denial and shock, i.e., the first stage of grief which could last from a few hours to a week or more [40]. LaRoche and colleagues seem to confuse delayed grief with an absence of response as a result of shock, since in their definition, "delayed grief" was marked by an onset of responses within three months after an absence of response immediately following the loss; and this, they termed "pathological" [54].

Several researchers have studied chronic grief, but definitions of "chronic" vary. Turner and colleagues considered grief reactions after one month following miscarriage as prolonged [55]. As the normal course of grief is expected to last for at least six months to a year, these responses can hardly be considered chronic reactions to pregnancy loss. A time frame of about a year as a normal grief trajectory following pregnancy loss was used in two studies $[52,56]$, and in only one study were intense grief responses in the first two years following pregnancy loss considered to be a normal response to the loss [5].

Sometimes the "replacement child syndrome" $[57,58]$ is mentioned in connection with pregnancy loss $[49,59]$. This syndrome could be regarded as a masked grief reaction, as grief is repressed and the feelings of emptiness engendered by the loss of the baby are assuaged by the birth of another child [58]. Moreover, the subsequent child is idealized in a way which could be regarded as a maladaptive behavior, one of the key signs of masked grief [43]. In two studies the "replacement child syndrome" is used as a possible indicator of pathological grief $[60,61]$. In these studies an over-idealization of the dead infant and not seeing the subsequent child as a separate individual are used as key signs of pathological grief. In some studies, maladaptive behavior such as being socially immobilized $[11,36$, $60,62-65]$, or somatic complaints $[11,36,63,64]$ are used as indicators of 


\section{6 / JANSSEN, CUISINIER AND HOOGDUIN}

Table 1. Empirical Studies on Pathological Grief Following Pregnancy Loss

\begin{tabular}{|c|c|c|c|}
\hline $\begin{array}{l}\text { Research Group; } \\
\text { Year of Publication }\end{array}$ & $N$ & Kind of Loss & Definition \\
\hline $\begin{array}{l}\text { Kennell, Slyter, and Klaus } \\
(1970)\end{array}$ & 18 Women & Neonatal death & Pathological grief \\
\hline $\begin{array}{l}\text { Wolff, Nielsen, and Schiller } \\
(1970)\end{array}$ & $\begin{array}{l}50 \text { Women initially, } \\
40 \text { Women tong } \\
\text { term }\end{array}$ & Stillbirth & Atypical grief reaction \\
\hline Cullberg (1972) & 56 Women & Perinatal death & $\begin{array}{l}\text { Chronic maladaptive } \\
\text { behavior }\end{array}$ \\
\hline Corney and Horton (1974) & 1 Woman & Spontaneous abortion & Pathological grief \\
\hline $\begin{array}{l}\text { Benfield, Leib, and Vollman } \\
\text { (1978) }\end{array}$ & 50 Couples & $\begin{array}{l}\text { Neonatal death (within } \\
42 \text { days after birth) }\end{array}$ & Pathological grieving \\
\hline Helmrath and Steinitz (1978) & 7 Couples & Neonatal death & Pathological grief \\
\hline Lewis and Page (1978) & 1 Woman & Stillbirth & Failed mourning \\
\hline $\begin{array}{l}\text { Rowe, Clyman, Green, } \\
\text { Mikkelsen, Haight, and } \\
\text { Ataide (1978) }\end{array}$ & 26 Women & $\begin{array}{l}\text { Perinatal loss } \\
\text { (stillbirth, neonatal loss) }\end{array}$ & $\begin{array}{l}\text { Morbid or prolonged } \\
\text { grief reactions }\end{array}$ \\
\hline $\begin{array}{l}\text { Clyman, Green, Rowe, } \\
\text { Mikkelsen, and Ataide (1980) }\end{array}$ & $\begin{array}{l}35 \text { Women and } \\
26 \text { Men }\end{array}$ & Neonatal loss & Unresolved grief \\
\hline Stack (1980) & $\begin{array}{l}5 \text { Women } \\
\text { (case studies) }\end{array}$ & $\begin{array}{l}\text { Spontaneous } \\
\text { abortion }\end{array}$ & Pathological grief \\
\hline
\end{tabular}




\begin{tabular}{|c|c|c|c|}
\hline $\begin{array}{l}\text { Specification } \\
\text { Operationalization }\end{array}$ & Measures & $\begin{array}{c}\text { Time of } \\
\text { Assessment }\end{array}$ & Outcome \\
\hline $\begin{array}{l}\text { Lindemann's description of } \\
\text { distorted grief }\end{array}$ & $\begin{array}{l}\text { Semistructured } \\
\text { interview and } \\
\text { self-developed } \\
\text { questionnaire }\end{array}$ & $\begin{array}{l}\text { Between } 3 \text { and } 22 \\
\text { weeks }\end{array}$ & 1 of $18=5.6 \%$ \\
\hline Severe emotional reaction & $\begin{array}{l}\text { Interview (aiso } \\
\text { aimed at } \\
\text { intervention) }\end{array}$ & $\begin{array}{l}\text { I at } 2 \text { days; } \\
\text { II at } 4 \text { days } \\
\text { One to several } \\
\text { assessments at } \\
\text { one to three years }\end{array}$ & $\begin{array}{l}2 \text { of } 50=4 \% \\
\text { (they also had } \\
\text { psychological } \\
\text { problems before } \\
\text { the loss) }\end{array}$ \\
\hline $\begin{array}{l}\text { Psychosis, anxiety disorder, phobia, } \\
\text { obsessive thoughts, depression }\end{array}$ & $\begin{array}{l}\text { Interview } \\
\text { (psychiatric) }\end{array}$ & $\begin{array}{l}\text { Between } 1 \text { and } 2 \\
\text { years }\end{array}$ & 19 of $56=33.9 \%$ \\
\hline $\begin{array}{l}\text { Crying episodes, increased } \\
\text { imitability, seli-mutilation behavior, } \\
\text { depression, anger, and anxiety }\end{array}$ & $\begin{array}{l}\text { Psychiatric } \\
\text { consultation }\end{array}$ & At 4 months & \\
\hline Criteria Lindemann (1944) & $\begin{array}{l}\text { Sell-developed } \\
\text { questionnaire }\end{array}$ & $\begin{array}{l}\text { Between } 11 \text { to } 97 \\
\text { days }\end{array}$ & $\begin{array}{l}1 \text { of } 50=2 \% \\
\text { (woman had } \\
\text { already received } \\
\text { psychiatric care } \\
\text { during pregnancy) }\end{array}$ \\
\hline Criteria Lindemann (1944) & Interview & $\begin{array}{l}\text { Between } 4 \text { to } \\
8 \text { months }\end{array}$ & $0 \%$ \\
\hline $\begin{array}{l}\text { Depression and difficulty with } \\
\text { caring for the subsequent child } \\
\text { (Replacement Child Syndrome) }\end{array}$ & $\begin{array}{l}\text { Clinical } \\
\text { observation }\end{array}$ & At 1 year & \\
\hline $\begin{array}{l}\text { Grief apparent longer than } 12 \text { to } 20 \\
\text { months after the loss }\end{array}$ & $\begin{array}{l}\text { Open-ended } \\
\text { interview and } \\
\text { observation } \\
\text { based on state- } \\
\text { ments made by } \\
\text { the women }\end{array}$ & $\begin{array}{l}\text { Between } 10 \text { to } 22 \\
\text { months }\end{array}$ & 6 of $26=23.1 \%$ \\
\hline $\begin{array}{l}\text { Thoughts of the death continuously } \\
\text { there, but now starting to get out and } \\
\text { about or "Immobilized" either emotionally } \\
\text { or in their daity activities by the death }\end{array}$ & $\begin{array}{l}\text { Open-ended } \\
\text { interview }\end{array}$ & $\begin{array}{l}\text { Between } 2 \text { to } 4 \\
\text { months }\end{array}$ & 21 of $61=34.4 \%$ \\
\hline $\begin{array}{l}\text { A vivid clear memory of events surround- } \\
\text { ing the loss: frequent flashing of the } \\
\text { events of the day or of specific scenes of } \\
\text { the loss; an anniversary effect, either on } \\
\text { the date of the miscarriage or on the cal- } \\
\text { culated birth date; persistence of affect, } \\
\text { such as sadness or anger, when talking } \\
\text { about the loss, and flooding of emotion } \\
\text { at the time of a subsequent crisis }\end{array}$ & $\begin{array}{l}\text { Psycho- } \\
\text { therapeutic } \\
\text { interview }\end{array}$ & $\begin{array}{l}\text { Between } 4 \text { months } \\
\text { to } 21 \text { years }\end{array}$ & \\
\hline
\end{tabular}


28 / JANSSEN, CUISINIER AND HOOGDUIN

Table 1. (Cont'd.)

\begin{tabular}{llll}
\hline $\begin{array}{l}\text { Research Group; } \\
\text { Year of Publication }\end{array}$ & $N$ & \multicolumn{1}{c}{ Kind of Loss } & \multicolumn{1}{c}{ Definition } \\
\hline $\begin{array}{l}\text { Forrest, Standish, and } \\
\text { Baum (1982) }\end{array}$ & 50 Couples & $\begin{array}{l}\text { Perinatal death } \\
\text { (stillbirth or neonatal } \\
\text { death within 7 days } \\
\text { after birth) }\end{array}$ & Atypical grief reactions \\
\hline
\end{tabular}

LaRoche et al. (1982)

31 Women

Perinatal loss

Inappropriate grief

reactions

Laurell-Borulf (1982)

67 Women

Stillbirth

Incomplete mourning

LaRoche et al. (1984)

30 Women;

Perinatal death

Pathological grief

17 reassessed,

13 new cases 


\begin{tabular}{|c|c|c|c|}
\hline $\begin{array}{l}\text { Specification/ } \\
\text { Operationalization }\end{array}$ & Measures & $\begin{array}{c}\text { Time of } \\
\text { Assessment }\end{array}$ & Outcome \\
\hline $\begin{array}{l}\text { Psychiatric and psychosomatic } \\
\text { disorders based on Parkes and } \\
\text { Brown (anxiety, somatic } \\
\text { symptoms, impairment of social } \\
\text { functioning and depression) }\end{array}$ & $\begin{array}{l}\text { Semi-structured } \\
\text { interview and two } \\
\text { standardized self- } \\
\text { rating scales to } \\
\text { measure psychiatric } \\
\text { disorder (General } \\
\text { Health Question- } \\
\text { naire(GHI) to give } \\
\text { a general assess- } \\
\text { ment of psychiatric } \\
\text { disorder and the } \\
\text { Leeds Scales which } \\
\text { gives information } \\
\text { about presence of } \\
\text { depression and } \\
\text { anxiety) }\end{array}$ & $\begin{array}{l}\text { I at } 6 \text { months; } \\
\text { II at } 14 \text { months } \\
\text { (Subjects were } \\
\text { divided into control } \\
\text { and experimental } \\
\text { group, in which the } \\
\text { experimental group } \\
\text { received care after } \\
\text { the loss) }\end{array}$ & $\begin{array}{l}\text { ASI: } 12 \text { of } 35 \\
(=34.3 \%) \text { had high } \\
\text { GHI; } 17 \text { of the } 35 \\
(=48.6 \%) \text { on Leeds } \\
\text { ASII } 5 \text { of the } 30 \\
(=16.7 \%) \text { on GHI } \\
\text { and } 2 \text { of the } 30 \\
(=6.7 \%) \text { on Leeds }\end{array}$ \\
\hline $\begin{array}{l}\text { When grief is overly intense or } \\
\text { shallow or absent }\end{array}$ & $\begin{array}{l}\text { Clinical observation } \\
\text { and evaluation of } \\
\text { the items }\end{array}$ & $\begin{array}{l}\text { I at one to two days; } \\
\text { II at two to three } \\
\text { weeks; } \\
\text { III at } 3 \text { months }\end{array}$ & 11 of $31=35.5 \%$ \\
\hline $\begin{array}{l}\text { Bad outcome based on having } \\
\text { met fewer than } 8 \text { of } 11 \text { criteria } \\
\text { (self-developed). No repression } \\
\text { of trauma, talk in realistic way } \\
\text { about event, no idealization of } \\
\text { dead infant, realistic view at } \\
\text { guilt feelings, no blaming of } \\
\text { others, ability to forgive self and } \\
\text { others, seeing subsequent child } \\
\text { as individual, competent social } \\
\text { life, having no psychological } \\
\text { symptoms as a result of the } \\
\text { loss, no frequent thoughts } \\
\text { about the baby, no uncontrolled } \\
\text { emotions when talking about } \\
\text { the event. }\end{array}$ & $\begin{array}{l}\text { Unstructured } \\
\text { interview }\end{array}$ & $\begin{array}{l}\text { Between } 12 \text { to } 14 \\
\text { years }\end{array}$ & 21 of $67=31.3 \%$ \\
\hline Depression & $\begin{array}{l}\text { Clinical interview and } \\
\text { standardized rating } \\
\text { scales of depression } \\
\text { (BDI) and a mourn- } \\
\text { ing scale which was } \\
\text { originally developed } \\
\text { by Kennel and Klaus } \\
\text { (1970) and was } \\
\text { adapted by the } \\
\text { authors }\end{array}$ & $\begin{array}{l}\text { I at one to two days; } \\
\text { II at two to three } \\
\text { weeks; } \\
\text { IIl at } 3 \text { months; } \\
\text { IV at one to two } \\
\text { years }\end{array}$ & $\begin{array}{l}\text { At AS IV: } 4 \text { of } 30= \\
13.3 \%\end{array}$ \\
\hline
\end{tabular}




\section{0 / JANSSEN, CUISINIER AND HOOGDUIN}

Table 1. (Cont'd.)

\begin{tabular}{llll}
\hline $\begin{array}{l}\text { Research Group; } \\
\text { Year of Publication }\end{array}$ & $N$ & Kind of Loss & Definition \\
\hline $\begin{array}{l}\text { Nicol, Tompkins, Campbell, } \\
\text { and Syme (1986) }\end{array}$ & 110 Women & $\begin{array}{l}\text { Perinatal loss } \\
\text { (stillbirth, neonatal } \\
\text { death within 28 days } \\
\text { after birth) }\end{array}$ & $\begin{array}{l}\text { Pathological } \\
\text { bereavement }\end{array}$ \\
\hline
\end{tabular}

\begin{tabular}{|c|c|c|c|}
\hline $\begin{array}{l}\text { Tudehope, Iredeil, Rodgers, } \\
\text { and Gunn (1986) }\end{array}$ & 67 Couples & $\begin{array}{l}\text { Neonatal death and } \\
\text { postneonatal death }\end{array}$ & Pathological grief \\
\hline
\end{tabular}

$\begin{array}{llll}\text { Murray and Callan (1988) } & \begin{array}{l}91 \text { Women and } \\ 39 \text { Men }\end{array} & \begin{array}{l}\text { Perinatal death } \\ \text { (stilbirth or neonatal } \\ \text { death within 28 days } \\ \text { after birth) }\end{array} & \begin{array}{l}\text { Personal adjustment } \\ \text { problems }\end{array} \\ & & \end{array}$

Smith and Borgers (1988-89)

115 Women and
61 Men

Perinatal loss

(miscarriage, stillibirth, neonatal loss, infant death)

Atypical response

Spontaneous abortion 


\begin{tabular}{|c|c|c|c|}
\hline $\begin{array}{l}\text { Specification } \\
\text { Operationalization }\end{array}$ & Measures & $\begin{array}{c}\text { Time of } \\
\text { Assessment }\end{array}$ & Outcome \\
\hline $\begin{array}{l}\text { Marked deterioration in physical } \\
\text { and mental health (general } \\
\text { nervousness, insomnia, } \\
\text { headaches, excessive tiredness, } \\
\text { nightmares, persistent fears, } \\
\text { depression, fear of nervous } \\
\text { breakdown, feelings of panic, and } \\
\text { repeated peculiar thoughts) and } \\
\text { increased social adjustment } \\
\text { problems, based on criteria } \\
\text { Lindemann (1944) }\end{array}$ & $\begin{array}{l}\text { Standardized scale; } \\
\text { General Health } \\
\text { Inventory }\end{array}$ & $\begin{array}{l}\text { Between } 6 \text { to } 36 \\
\text { months }\end{array}$ & 23 of $110=21 \%$ \\
\hline $\begin{array}{l}\text { One or more serious symploms } \\
\text { disturbing day to day functioning } \\
\text { (sleep disturbances: insomnia, } \\
\text { nightmares, early waking/ } \\
\text { depression, uncontrolled crying' } \\
\text { anorexia, weight loss/nervous- } \\
\text { ness, anxiety/social withdrawal } \\
\text { morbid preoccupation/guit, anger, } \\
\text { hostility/psychosomaticsymptoms) }\end{array}$ & Interview & At 2 months & 21 of $67=31.3 \%$ \\
\hline $\begin{array}{l}\text { Depression, decreased selt- } \\
\text { esteem and decreased } \\
\text { psychological well-being }\end{array}$ & $\begin{array}{l}\text { Structured stan- } \\
\text { dardized self-report } \\
\text { measures: a global } \\
\text { rating of well-being } \\
\text { or happiness, a self- } \\
\text { esteem scale, and } \\
\text { from the Health and } \\
\text { Daily Living Form an } \\
\text { 18-item measure of } \\
\text { global depression }\end{array}$ & $\begin{array}{l}\text { For two-thirds of the } \\
\text { parents within } 2 \\
\text { years, one-third } \\
\text { after two years. } \\
\text { (Unclear how long: } \\
\text { mean-time for men } \\
\text { was } 24.7 \text { months } \\
\text { and for women } 27.4 \\
\text { months) }\end{array}$ & $\begin{array}{l}\text { Parents were sig- } \\
\text { nificantly more } \\
\text { depressed than a } \\
\text { community sample, } \\
\text { but had fewer } \\
\text { symptoms than } \\
\text { depressed patients }\end{array}$ \\
\hline $\begin{array}{l}\text { Denial, atypical response, social } \\
\text { desirability, guilt, anger/hostility, } \\
\text { despair, social isolation, loss of } \\
\text { control, rumination, depersonali- } \\
\text { zation, somatization, and death } \\
\text { anxiety }\end{array}$ & $\begin{array}{l}\text { Standardized self- } \\
\text { report scale: Grief } \\
\text { Experience Inven- } \\
\text { tory (GEI) that con- } \\
\text { sists of } 12 \text { subscales }\end{array}$ & $\begin{array}{l}\text { Between } 6 \text { months } \\
\text { and } 7 \text { years }\end{array}$ & \\
\hline Psychiatric disorder & $\begin{array}{l}\text { Present State Exam- } \\
\text { ination to assess } \\
\text { mental state and } \\
\text { Standardized Rating } \\
\text { Scales to assess } \\
\text { depression (Madrs, } \\
\text { Hamilton, BDI) } \\
\text { marital relationship } \\
\text { (MMQ), personality } \\
\text { (EPO) and social } \\
\text { adjustment (SAS-M) }\end{array}$ & I at 4 weeks & 32 of the $67=47.8 \%$ \\
\hline
\end{tabular}


Table 1. (Cont'd.)

\begin{tabular}{|c|c|c|c|}
\hline $\begin{array}{l}\text { Research Group; } \\
\text { Year of Publication }\end{array}$ & $N$ & Kind of Loss & Definition \\
\hline $\begin{array}{l}\text { Cuisinier, Janssen, } \\
\text { Timmers, and Hoogduin } \\
\text { (1990) }\end{array}$ & 50 Women & $\begin{array}{l}\text { Miscarriage and } \\
\text { stillbirth }\end{array}$ & Disturbed mourning \\
\hline $\begin{array}{l}\text { Lasker and Toedter } \\
\text { (1991) }\end{array}$ & $\begin{array}{l}138 \text { Women and } \\
56 \text { Men }\end{array}$ & $\begin{array}{l}\text { Perinatal loss } \\
\text { (spontaneous abortion, } \\
\text { ectopic pregnancy, } \\
\text { stillbirth, and } \\
\text { neonatal death) }\end{array}$ & Pathological grief \\
\hline Turner et al. (1991) & 300 Women & Miscarriage & $\begin{array}{l}\text { Prolonged grief } \\
\text { Unresolved grief }\end{array}$ \\
\hline Hunfeld et al. (1993) & 41 Women & $\begin{array}{l}\text { Perinatal death or } \\
\text { baby diagnosed as } \\
\text { severely malformed }\end{array}$ & Pathological grief \\
\hline
\end{tabular}

pathological grief. These reactions could also be considered as forms of masked grief [43]; since they result from the loss of the baby, these might both be seen as indirect ways of expressing repressed grief. As maladaptive behavior or physical symptoms also form part of the normal course of grief [44], they should only be considered pathological if these reactions are present, but the bereaved is unable to connect them with the loss [43]. This criterion was not included in the definitions of pathological grief in the empirical studies.

Psychiatric symptoms are often looked to as an indication of "pathological grief" or exaggerated grief. Throughout the empirical studies, however, opinions vary as to the moment when responses have become so intense that they can no longer be considered a normal response to a loss. In some studies, the presence of psychological symptoms is used as an indicator of pathological grief $[10,11,36$, $60,64-66]$, whereas in others only a psychiatric disorder is considered pathological $[17,63,67]$. Some researchers employ the criterion of seeking psychiatric or psychotherapeutic treatment following pregnancy loss as an indication of pathological grief $[3,4,7,8]$. 


\begin{tabular}{|c|c|c|c|}
\hline $\begin{array}{l}\text { Specification/ } \\
\text { Operationalization }\end{array}$ & Measures & $\begin{array}{c}\text { Time of } \\
\text { Assessment }\end{array}$ & Outcome \\
\hline $\begin{array}{l}\text { Delayed griel (grief absent at } \\
\text { first and strong reactions after } \\
\text { a long period of time or absent } \\
\text { grief) and chronic grief (after } 2 \\
\text { years having one of the following } \\
\text { feelings: reliving the experience, } \\
\text { searching for the baby, anger, } \\
\text { hostility, guilt, anxiety, loss of } \\
\text { energy, lowered self-esteem } \\
\text { or feeling useless) }\end{array}$ & $\begin{array}{l}\text { Semi-structured } \\
\text { interview }\end{array}$ & Within 5 years & $\begin{array}{l}22 \% \text { (chronic } 18 \% \text {; } \\
\text { delayed } 4 \% \text { ) }\end{array}$ \\
\hline Chronic and delayed grief & $\begin{array}{l}\text { Perinatal Grief Scale } \\
\text { (PGS). Including } 3 \\
\text { subscales Active } \\
\text { Grief, Difficulty } \\
\text { Coping and Despair, } \\
\text { with the last two } \\
\text { being an indication } \\
\text { of problematic } \\
\text { outcome }\end{array}$ & $\begin{array}{l}\text { I within } 2 \text { months; } \\
\text { II at } 1 \text { year; } \\
\text { III at } 2 \text { years }\end{array}$ & \\
\hline Grief apparent after 1 month & Interview & At 1 month & $\begin{array}{l}21 \% \text { (absent grief } \\
4 \% \text { ) }\end{array}$ \\
\hline Severe mental imbalance & $\begin{array}{l}\text { Clinical ratings } \\
\text { based on written } \\
\text { reports of interviews }\end{array}$ & At 3 months & $\begin{array}{l}22 \% \text { (somatic signs: } \\
14 \% \text {; psychic signs: } \\
14 \% \text {; social signs: } \\
6 \% \text { ) }\end{array}$ \\
\hline
\end{tabular}

In conclusion, the subtypes of pathological grief which are more frequently studied are chronic grief and exaggerated grief. In reviewing the definitions used for chronic grief, it becomes obvious that researchers have different views with regard to the normal time course of grief following pregnancy loss, and in general parents are expected to get over the loss in a relatively short time. A similar variety of views is found when one looks at the intensity of responses within the definitions of exaggerated grief. Psychological complaints are seen by some as a pathological response, whereas these might more easily indicate that pregnancy loss is a significant life event that, for a time, evokes a mental imbalance. In a few studies, the response was termed pathological if a psychiatric disorder had developed as a result of pregnancy loss. Delayed grief has been investigated only incidentally, and it is amazing that the absence of reactions only in the first weeks following a loss is sometimes considered pathological. As far as masked grief is concerned, the "replacement child syndrome" has received little empirical attention, and although physical symptomatology and maladaptive behaviors have been more widely studied, it remains unclear as to whether they do indeed result 
from the previous repression of grief and really do indicate pathological grief. In general, there is no consensus on definitions.

\section{Findings Related to Pathological Grief}

In the first year following miscarriage or perinatal loss, approximately 20 to 30 percent of women have been found to show "pathological" grief $[55,56,68]$, which, according to the definitions employed in those studies, can be classified under the chronic subtype of pathological grief. After two years 20 percent of the women still indicated that they had not been able to accept the miscarriage or stillbirth [5].

Delayed grief was thought to be present in 4 percent of women following either miscarriage or stillbirth [5]. In 13.2 percent of the parents, mainly men, a delayed response was found at two years following pregnancy loss [52].

In the masked subtype of pathological grief, no conclusion can be drawn with regard to the occurrence of the "replacement child syndrome." An impairment in social functioning or somatic complaints are found in approximately 20 to 30 percent of men and women within the first six months following neonatal loss [62, 63], but it is not certain whether these reactions can be regarded as pathological since it is not known whether they occurred as a result of repressing grief.

With regard to exaggerated grief, around 30 to 50 percent of men and women show psychological complaints such as feelings of depression and anxiety within the first year following perinatal loss [11, 65]. After a year this percentage drops to approximately 10 percent $[11,17]$ to 30 percent $[10,36]$. In one study [60], women's grief was examined twelve to fourteen years following stillbirth. After this time 31 percent of the women still evidenced severe psychological complaints. About 10 to 15 percent of the women who had experienced a perinatal loss met the criteria for a psychiatric disorder in the first two years following the loss $[17,63]$. Women rarely seek psychiatric care following perinatal loss; fewer than 6 percent of women asked for this during the first year following neonatal death $[3,7,8]$, and about 4 percent asked for it within the first three years following stillbirth [4]. In these studies most women who had previously received psychiatric care, needed it again after the loss of their child.

Of the studies on the psychological impact of miscarriage [67, 69-73], only one [67], terms a strong psychological response as "pathological." It has been reported that, within the first six months following miscarriage, about 30 to 50 percent of women show severe depressive symptomatology or symptoms of anxiety [70-73]. Approximately half of the women could be diagnosed as having a psychiatric disorder within the first three months following miscarriage $[67,69]$.

Before discussing the results, the design characteristics of the studies on pregnancy loss are first critically reviewed in the next section, as they might explain differences in results. 


\section{Design Characteristics of the Studies on Pregnancy Loss}

Studies on pregnancy loss conducted in the seventies and early eighties are characterized by relatively small sample sizes, often of less than fifty individuals $[3,17,54,56]$. Although some later studies, in particular those conducted the most recently, have used larger samples $[52,64]$, the frequent use of small samples, together with the fact that respondents are often not randomly selected, limits the generalizability of the results. For example, in the study by LaRoche and colleagues, half of the original research sample had dropped out by the follow-up assessment and were replaced by newly recruited women $[17,54]$. Others have recruited parents by means of newspaper announcements [5] or support groups $[36,64,66]$. It is highly likely that in groups formed, thus the number of parents found to evidence pathological grief would exceed the number that might be found in a randomly selected group. In future research, more attention will have to be paid to recruitment procedures.

Another shortcoming is that meager use is made of comparison groups consisting of women who are pregnant or who have given birth to a living baby. As the transition to parenthood can also be stressful [74-76], comparison designs should be advocated in order to gain information focused on the impact of pregnancy loss. Only a few studies which were not specifically concerned with pathological grief have used comparison group designs [72, 73, 77-79].

Although grief is a process and reactions change over time, repeated assessments of grief are only seldom carried out. The majority of studies include only one assessment of grief $[3,5,7,10,36,56,60,62,64-67]$. In the future in order to gain more knowledge on the course of grief following pregnancy loss, longitudinal studies with repeated assessments of grief, covering a relatively long period of time, should be conducted.

\section{DISCUSSION}

Research on grief following pregnancy loss is characterized by different methodological shortcomings. A major shortcoming, however, is that pathological grief is neither well defined nor measured. Based on the general bereavement literature, empirical studies on pathological grief following pregnancy loss were reviewed on the basis of four subtypes of pathological grief: chronic, delayed, masked, and exaggerated grief.

With regard to chronic grief reactions, the main issues are how long grief reactions can continue before they are considered to be abnormal and they might be seen as an indicator of pathological grief. An examination of the findings of studies on long-term grief following pregnancy loss reveals that parents are expected to get over the loss of their baby relatively quickly. What is also apparent, however, is that many women have not worked through their grief by the 
end of the first year. The more liberal view that grieving will last for one to two years after a pregnancy loss is more appropriate. This will be particularly true where the loss occurs later in the pregnancy. There is little real long-term research into chronic grief. It is sometimes reported that around 20 percent of women show chronic grief reactions, but this figure is derived from relatively short-term research, i.e., within a year [56]. The issue of long-term grieving in women following pregnancy loss has to be addressed further in future research.

From the few studies on delayed grief following pregnancy loss, it seems that this type of grief is apparent in only a small minority of women following such a loss. It might also be cautiously concluded that men are more prone to delayed grief than women. A delayed grief reaction is, however, empirically hard to identify. A small percentage of parents do not show any reaction to the loss at all. Although these parents are believed to repress feelings, it might be that they are not emotionally moved by the loss [45], or feelings have already subsided after a few days.

No firm conclusions can be drawn on the existence of the subtype of pathological grief known as "masked grief." In the first six months following pregnancy loss, women evidence somatic complaints and behavioral changes, but none of the studies showed conclusively that parents had developed behavioral changes or somatic complaints as a consequence of repressing grief. There was no evidence, therefore, of masked grief in the sense put forward by Worden [43]. It seems more likely that in the first months following pregnancy loss, a number of parents exhibit somatic complaints and an impairment in social functioning as a normal reaction to the loss. It may be that some parents do indeed develop masked grief reactions, but it cannot be ascertained with any degree of certainty how often this occurs.

The incidence of exaggerated grief varies markedly, depending on the criteria used and the time of assessment. The studies that have examined the presence of a psychiatric disorder in women following pregnancy loss have shown that about 10 to 15 percent of the women meet the criteria for a psychiatric disorder. From the scant research that has been carried out into the proportion of women who seek specific psychiatric support following pregnancy loss, it emerges that this applies to only a small minority, less than 10 percent of the women. It is however possible to draw some tentative conclusions from the information obtained. Most of the women who did so had received it earlier in life. It would seem that a pregnancy loss causes such severe stress to parents that it can trigger the recurrence of mental health problems [48]. Psychological complaints would seem to be fairly common among women following pregnancy loss. Depressive symptomatology is particularly common in the first six months, which is not surprising since grief and depression are very much linked [80, 81]. From the empirical studies in which psychological reactions were not labeled as pathological grief responses, it also appears that a substantial number of women (approximately 30 to 50\%) develop severe depressive symptomatology in the first six months following miscarriage. 
Taking altogether the findings of the empirical studies on pregnancy loss, it can be concluded that severe psychological complaints or behavioral changes and somatic complaints are fairly common responses in the first six months following pregnancy loss, since they are present in approximately 20 to 50 percent of women and men. A psychiatric disorder seems to be less common since only about 10 to 15 percent of the women develop such a disorder during the first two years following perinatal loss, and less than 10 percent of women seek specific psychiatric care. After two years, one in five women report that they have not been able to accept the loss. Delayed grief occurs in about 4 percent of the parents following pregnancy loss and seems to occur more often in men than in women. It must, however, be noted that these figures would have been lower if the definitions of pathological grief had been more stringent and the designs of the studies more rigorous.

For research purposes, and on the basis of this review, we would like to suggest a more narrow definition of pathological grief following pregnancy loss. We suggest that when parents still show great difficulty accepting the loss after one-and-a-half to two years, this might be viewed as a chronic grief response. Another symptom of difficulty in handling the loss would be if parents feel themselves to be in need of professional care because of the loss. Depressive reactions, somatic complaints and an impairment in social functioning in the first six months following pregnancy loss do not seem to be uncommon. A psychiatric mood disorder according to the DSM-IV criteria could, however, be an indication of an extreme response. Evidence of other psychiatric disorders such as anxiety disorder, post-traumatic stress disorder or substance-abuse disorder according to DSM-IV, could be an indication of an exaggerated grief response, while showing a delayed reaction to pregnancy loss after two years could be an indication of pathological grief.

Future research should be aimed at looking for the key signs of a problematic outcome after a loss experience. Stronger designs in which repeated assessments are taken over a period of two years or even longer after the loss should be advocated. Making use of a comparison group design might be helpful in distinguishing psychopathology that develops as a result of the loss experience from that which results from the normal transition to parenthood. Other psychiatric disturbances following pregnancy loss also have to be studied. For example, post-traumatic stress disorder has not yet been empirically studied in relation to pregnancy loss, although Condon [82] has already noted similarities in the reactions a woman showed following pregnancy loss and the criteria for this disorder.

Research has often concluded that a relatively large number of women seem to be at risk of a problematic outcome following pregnancy loss. This conclusion is partly a result of flaws in the empirical studies in this field. If a more narrower and more concordant definition of pathological grief following pregnancy loss were employed, the percentage of parents evidencing pathological grief would very likely be substantially lower than those so far reported. Probably only a small 
minority of women (perhaps around 10 to $15 \%$ ) are actually at risk of developing psychiatric disturbances following pregnancy loss. Although the impact of a pregnancy loss has long been underestimated, and it now seems clear that women in particular may be greatly affected psychologically by pregnancy loss and may in fact show psychiatric symptoms during the first six months, most women seem to be able to recover from a pregnancy loss in the course of time, drawing on their own strength. However, some parents might need bereavement counseling to guide them through the grief process in order to prevent complicated grief reactions. In some cases specialized professional care will be needed to help the parents work through grief and enable them finally to accept the loss of their baby.

\section{REFERENCES}

1. S. Bourne, The Psychological Effects of Stillbirths on Women and Their Doctors, Journal of the Royal College of General Practitioners, 16, pp. 103-112, 1968.

2. P. F. H. Giles, Reactions of Women to Perinatal Death, Australian and New Zealand Journal of Obstetrics and Gynaecology, 10, pp. 207-210, 1970.

3. J. H. Kennell, H. Slyter, and M. H. Klaus, The Mourning Response of Parents to the Death of a Newborn Infant, New England Journal of Medicine, 13, pp. 344-349, 1970.

4. J. R. Wolff, P. E. Nielson, and P. Schiller, The Emotional Reaction to a Stillbirth, American Journal of Obstetrics and Gynecology, 1, pp. 73-77, 1970.

5. M. C. J. Cuisinier, H. Janssen, L. Timmers, and C. A. L. Hoogduin, Verliesverwerking en Ervaren Steun bij Miskraam en Doodgeboorte [Coping Process and Psychosocial Support at Miscarriage and Stillbirth], Nederlands Tijdschrift voor Geneeskunde, 134, pp. 2395-2399, 1990.

6. E. D. Stierman, Emotional Aspects of Perinatal Death, Clinical Obstetrics and Gynecology, 30, pp. 352-361, 1987.

7. D. G. Benfield, S. A. Leib, and J. H. Vollman, Grief Response of Parents to Neonatal Death and Parent Participation in Deciding Care, Pediatrics, 62:2, pp. 171-177, 1978.

8. T. A. Helmrath and E. M. Steinitz, Death of an Infant: Parental Grieving and the Failure of Social Support, Journal of Family Practice, 6:4, pp. 785-790, 1978.

9. W. L. Hildebrand and R. L. Schreiner, Helping Parents Cope with Perinatal Death, American Family Physician, 22, pp. 121-125, 1980.

10. J. Culberg, Mental Reactions of Women to Perinatal Death, in Proceedings of the Third International Congress on Psychosomatic Medicine in Obstetrics and Gynaecology, Karger, Basel, Switzerland, pp. 325-329, 1972.

11. G. C. Forrest, E. Standish, and J. D. Baum, Support after Perinatal Death: A Study of Support and Counselling after Perinatal Bereavement, British Medical Journal, 285, pp. 1475-1479, 1982.

12. R. J. Harmon, A. D. Glicken, and R. E. Siegel, Neonatal Loss in the Intensive Care Nursery: Effects of Maternal Grieving and a Program for Intervention, Journal of the American Academy of Child and Adolescent Psychiatry, 23, pp. 68-71, 1984.

13. K. J. Doka, Disenfranchised Grief: Recognizing Hidden Sorrow, Lexington Books, New York, 1989. 
14. J. T. Condon, Management of Established Pathological Grief Reaction after Stillbirth, American Journal of Psychiatry, 143, pp. 987-992, 1986.

15. R. C. W. Hall, T. P. Beresford, and J. E. Quinones, Grief following Spontaneous Abortion, Psychiatric Clinics of North America, 10, pp. 405-420, 1987.

16. E. Kirkley-Best and K. R. Kellner, The Forgotten Grief: A Review of the Psychology of Stillbirth, American Journal of Orthopsychiatry, 52, pp. 420-429, 1982.

17. C. LaRoche, M. Lalinec-Michaud, F. Engelsmann, N. Fuller, M. Copp, and L. McQuade-Soldatos, Grief Reactions to Perinatal Death: A Follow-Up Study, Canadian Joumal of Psychiatry, 29, pp. 14-19, 1984.

18. I. G. Leon, Short-Term Psychotherapy for Perinatal Loss, Psychotherapy, 24, pp. 186-195, 1987.

19. S. Phipps, Mourning Response and Intervention in Stillbirth: An Alternative Genetic Counseling Approach, Social Biology, 28, pp. 1-13, 1981.

20. T. A. Rando, How to Go On Living When Someone You Love Dies, Bantam Books, New York, 1991.

21. J. M. Stack, The Psychodynamics of Spontaneous Abortion, American Journal of Orthopsychiatry, 54, pp. 162-167, 1984.

22. R. D. Day and D. Hooks, Miscarriage: A Special Type of Family Crisis, Family Relations, 36, pp. 305-310, 1987.

23. J. A. Nichols, Perinatal Death, in Disenfranchised Grief: Recognizing Hidden Sorrow, K. J. Doka (ed.), Lexington Books, New York, pp. 117-126, 1989.

24. W. J. Wassner, The Pastoral Dynamics of Miscarriage, Pastoral Psychology, 40, pp. 113-121, 1991.

25. S. Borg and J. Lasker, When Pregnancy Fails: Families Coping with Miscarriage, Ectopic Pregnancy, Stillbirth and Infant Death (Rev. Edition), Bantam Books, New York, 1988.

26. J. J. LaFerla and R. S. Good, Helping Patients Cope with Pregnancy Loss, Contemporary Obstetrics and Gynaecology, 25, pp. 107-115, 1985.

27. I. G. Leon, The Invisible Loss: The Impact of Perinatal Death on Siblings, Journal of Psychosomatic Obstetrics and Gynaecology, 5, pp. 1-14, 1986.

28. E. A. G. C. Keirse, Eerste Opvang bij Perinatale Sterfte: Gedragingen en Attitudes van Ouders en Zorgverleners (Psychosocial Care and Support in the Immediate Aftermath of Perinatal Death: Behaviors and Attitudes of Parents and Caregivers), ACCO, Leuven/Amersfoort, 1989.

29. I. G. Leon, When a Baby Dies. Psychotherapy for Pregnancy and Newborn Loss, Yale University Press, New Haven, 1990.

30. R. B. Black, Women's Voices after Pregnancy Loss: Couples' Patterns of Communication and Support, Social Work in Health Care, 16, pp. 19-36, 1991.

31. P. Conway and D. Valentine, Reproductive Losses and Grieving, Journal of Social Work and Human Sexuality, 6, pp. 43-64, 1988.

32. E. Kirkley-Best and C. VanDevere, The Hidden Family Grief: An Overview of Grief in the Family following Perinatal Death, Intemational Journal of Family Psychiatry, 7, pp. 419-437, 1986.

33. S. Phipps, The Subsequent Pregnancy after Stillbirth: Anticipatory Parenthood in the Face of Uncertainty, International Journal of Psychiatry in Medicine, 15, pp. 243-264, 1985-86. 
34. M. C. J. Cuisinier, J. C. Kuijpers, C. A. L. Hoogduin, C. P. H. M. de Graauw, and H. J. E. M. Janssen, Miscarriage and Stillbirth: Time Since the Loss, Grief Intensity and Satisfaction with Care, European Journal of Obstetrics and Gynecology and Reproductive Biology, 52, pp. 163-168, 1993.

35. H. J. E. M. Janssen, A. van Minnen, M. C. J. Cuisinier, C. P. H. M. de Graauw, J. C. Kuijpers, C. A. L. Hoogduin, and A. P. J. Meershoek, Predictie van Verliesverwerking na een Miskraam (Prediction of Grief Intensity after a Miscarriage), Gedrag en Gezondheid, 20, pp. 226-235, 1992.

36. M. T. Nicol, J. R. Tompkins, N. A. Campbell, and G. J. Syme, Maternal Grieving Response after Perinatal Death, Medical Journal of Australia, 144, pp. 287-289, 1986.

37. L. J. Toedter, J. N. Lasker, and J. M. Alhadeff, The Perinatal Grief Scale: Development and Initial Validation, American Journal of Orthopsychiatry, 58, pp. 435-449, 1988.

38. W. Middleton, B. Raphael, N. Martinek, and V. Misso, Pathological Grief Reactions, in Handbook of Bereavement: Theory, Research, and Intervention, M. S. Stroebe, W. Stroebe, and R. O. Hansson (eds.), University Press, Cambridge, 1993.

39. E. Lindemann, Symptomatology and Management of Acute Grief, American Journal of Psychiatry, 101, pp. 141-148, 1944.

40. J. Bowlby, Loss, Sadness and Depression. Attachment and Loss: Volume III, Penguin Books, London, 1980.

41. C. M. Parkes, The First Year of Bereavement. A Longitudinal Study of the Reactions of London Widows to the Death of Their Husbands, Psychiatry, 33, pp. 444-467, 1970.

42. E. Kübler-Ross, On Death and Dying, Macmillan, New York, 1969.

43. J. W. Worden, Grief Counseling and Grief Therapy. A Handbook for the Mental Health Practitioner (2nd Edition), Routledge, London, 1991.

44. S. R. Shuchter and S. Zisook, The Course of Normal Grief, in Handbook of Bereavement: Theory, Research, and Intervention, M. S. Stroebe, W. Stroebe, and R. O. Hansson (eds.), University Press, Cambridge, 1993.

45. C. B. Wortman and R. C. Silver, The Myths of Coping with Loss, Journal of Consulting and Clinical Psychology, 57, pp. 349-357, 1989.

46. D. Peretz, Reaction to Loss, in Loss and Grief: Psychological Management in Medical Practice, B. Schoenberg, A. C. Carr, D. Peretz, and A. H. Kutscher (eds.), Colombia University Press, New York, pp. 20-35, 1970.

47. C. M. Parkes, Bereavement and Mental Illness. Part 1. A Clinical Study of the Grief of Bereaved Psychiatric Patients, British Journal of Medical Psychology, 38, pp. 1-12, 1965.

48. M. J. Horowitz, N. Wilner, C. Marmar, and J. Krupnick, Pathological Grief and the Activation of Latent Self-Images, American Journal of Psychiatry, 137, pp. 1157-1162, 1980.

49. S. Bourne and E. Lewis, Pregnancy after Stillbirth or Neonatal Death. Psychological Risk and Management, Lancet, 2, pp. 31-33, 1984.

50. C. M. Parkes, Bereavement and Mental Illness. Part 2. A Classification of Bereavement Reactions, British Journal of Medical Psychology, 38, pp. 13-26, 1965.

51. W. Stroebe and M. S. Stroebe, Determinants of Adjustment to Bereavement in Younger Widows and Widowers, in Handbook of Bereavement: Theory, Research, and Interventions, M. S. Stroebe, W. Stroebe, and R. O. Hansson (eds.), University Press, Cambridge, pp, 208-226, 1993. 
52. J. N. Lasker and L. J. Toedter, Acute versus Chronic Grief: The Case of Pregnancy Loss, American Journal of Orthopsychiatry, 61, pp. 510-522, 1991.

53. J. M. Stack, Spontaneous Abortion and Grieving, American Family Physicians, 21, pp. 99-102, 1980.

54. C. LaRoche, M. Lalinec-Michaud, F. Engelsmann, N. Fuller, M. Copp, and K. Vasilevsky, Grief Reactions to Perinatal Death: An Exploratory Study, Psychosomatics, 23, pp. 510-518, 1982.

55. M. J. Turner, G. M. Flannelly, M. Wingfield, M. J. Rasmussen, R. Ryan, S. Cullen, R. Maguire, and J. M. Stronge, The Miscarriage Clinic: An Audit of the First Year, British Journal of Obstetrics and Gynaecology, 98, pp. 306-308, 1991.

56. J. Rowe, R. Clyman, C. Green, C. Mikkelsen, J. Haight, and L. Ataide, Follow-Up of Families Who Experience a Perinatal Death, Pediatrics, 62, pp. 166-170, 1978.

57. A. C. Cain and B. S. Cain, On Replacing a Child, Journal of the American Academy of Child Psychiatry, 3, pp. 443-455, 1964.

58. E. O. Poznanski, The "Replacement Child": A Saga of Unresolved Parental Grief, Behavioral Pediatrics, 81, pp. 1190-1193, 1972.

59. R. J. L. Oglethorpe, Parenting after Perinatal Bereavement: A Review of the Literature, Journal of Reproductive and Infant Psychology, 7, pp. 227-244, 1989.

60. Y. Laurell-Borulf, Longterm Adjustment after an Emotional Crisis, in Krislosning I Langtidsperspektive, Studenlitteratur (ed.), Lund, Sweden, pp. 157-167, 1982.

61. E. Lewis and A. Page, Failure to Moum a Stillbirth: An Overlooked Catastrophe, Journal of Medical Psychology, 51, pp. 237-241, 1978.

62. R. I. Clyman, C. Green, L. Rowe, C. Mikkelsen, and L. Ataide, Issues Concerning Parents after the Death of Their Newborn, Critical Care Medicine, 8, pp. 215-218, 1980.

63. J. A. M. Hunfeld, J. W. Wladimiroff, J. Passchier, M. Uniken Venema-van Uden, P. G. Frets, and F. Verhage, Emotional Reactions in Women in Late Pregnancy (24 Weeks or Longer) following the Ultrasound Diagnosis of a Severe or Lethal Fetal Malformation, Prenatal Diagnosis, 13, pp. 603-612, 1993.

64. A. C. Smith and S. B. Borgers, Parental Grief Response to Perinatal Death, Omega, 19, pp. 203-214, 1988-89.

65. D. I. Tudehope, J. Iredell, D. Rodgers, and A. Gunn, Neonatal Death: Grieving Families, Medical Journal of Australia, 144, pp. 290-291, 1986.

66. J. Murray and V. J. Callan, Predicting Adjustment to Perinatal Death, British Joumal of Medical Psychology, 61, pp. 237-244, 1988.

67. T. Friedman and D. Gath, The Psychiatric Consequences of Spontaneous Abortion, British Journal of Psychiatry, 155, pp. 810-813, 1989.

68. C. H. Zeanah, Adaptation following Perinatal Loss: A Critical Review, Journal of the American Academy of Child and Adolescent Psychiatry, 28, pp. 467-480, 1989.

69. M. Garel, B. Blondel, N. Lelong, C. Papin, S. Bonenfant, and M. Kaminski, Réactions Dépressives après une Fausse Couche (Depressive Reactions after Miscarriage), Fertilité Contraception Sexualité, 20, pp. 75-81, 1992.

70. C. Jackman, H. M. McGee, and M. Turner, The Experience of Psychological Impact of Early Miscarriage, Irish Journal of Psychology, 12, pp. 108-120, 1991.

71. S. Naor, M. Assael, M. Pecht, N. Trainin, and D. Samuel, Correlation between Emotional Reaction to Loss of an Unborn Child and Lymphocyte Response to Mitogenic 
Stimulation in Women, Israel Joumal of Psychiatry and Related Sciences, 20, pp. 231-239, 1983.

72. R. Neugebauer, J. Kline, P. O'Connor, P. Shrout, J. Johnson, A. Skodol, J. Wicks, and M. Susser, Determinants of Depressive Symptoms in the Early Weeks after Miscarriage, American Journal of Public Health, 82, pp. 1332-1339, 1992.

73. R. Neugebauer, J. Kline, P. O'Connor, P. Shrout, J. Johnson, A. Skodol, J. Wicks, and M. Susser, Depressive Symptoms in Women in the Six Months after Miscarriage, American Journal of Obstetrics and Gynecology, 166, pp. 104-109, 1992.

74. C. E. Cutrona, Nonpsychotic Postpartum Depression: A Review of Recent Research, Clinical Psychology Review, 2, pp. 487-503, 1982.

75. S. A. Elliott, A. J. Rugg, J. P. Watson, and D. I. Brough, Mood Changes during Pregnancy and after the Birth of a Child, British Journal of Clinical Psychology, 22, pp. 295-308, 1983.

76. P. Romito, Unhappiness after Childbirth, in Effective Care in Pregnancy and Childbirth: Vol. II, I. Chalmers, M. Enkin, and M. J. N. C. Keirse (eds.), University Press, Oxford, pp. 1433-1446, 1989.

77. M. Clarke and A. J. Williams, Depression in Women after Perinatal Death, Lancet, 4, pp. 916-917, 1979.

78. H. J. E. M. Janssen, M. C. J. Cuisinier, C. A. L. Hoogduin, and C. P. H. M. de Graauw, Controlled Prospective Study on the Mental Health of Women following Pregnancy Loss, American Journal of Psychiatry, 153, pp. 226-230, 1996.

79. A. K. Thapar and A. Thapar, Psychological Sequelae of Miscarriage: A Controlled Study using the General Health Questionnaire and the Hospital Anxiety and Depression Scale, British Journal of General Practice, 42, pp. 94-96, 1992.

80. C. J. David, Grief, Mourning and Pathological Mourning, Primary Care, 2, pp. 81-92, 1975.

81. S. Freud, Trauer und Melancholie (Mourning and Melancholia), in, Gesammelte Werke Chronologisch Geordnet: Werke aus den Jahren 1913-1917 (Vol. 10), Imago Publishing, London, 1946.

82. J. T. Condon, Predisposition to Psychological Complications after Stillbirth: A Case Report, Obstetrics and Gynecology, 70, pp. 495-497, 1987.

Direct reprint requests to:

Hettie Janssen

University of Nijmegen

Department of Clinical Psychology

Postbox 9104

$6500 \mathrm{HE}$ Nijmegen

The Netherlands 